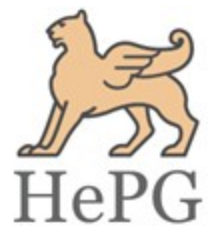

\title{
Taxonomic significance of Cyspsela in Vernonia anthelmintica Willd. and $V$. cinerea Less. (Asteraceae; tribe - Vernonieae): Structural manifestations
}

\author{
Tulika Talukdar \\ Department of Botany, A.P.C. Roy Govt. College, Siliguri, Darjeeling, West Bengal, India
}

Article history

Received: 6 July 2015

Accepted: 9 August 2015

Published online: 1 October 2015

(C) Talukdar, T. (2015)

Keywords

Cypsela; electron microscopy; indented key; morpho-anatomy; pappus; Vernonia

Publisher

Horizon e-Publishing Group

Corresponding Author

Tulika Talukdar

$\square_{\text {talukdartulip12@gmail.com }}$

\begin{abstract}
An investigation was carried out to reveal the taxonomic importance of cypselar features of Vernonia anthelmintica Willd. and Vernonia cinerea Less. through morpho-anatomical manifestations in the plesiomorphic tribe Vernonieae of the dicot family Asteraceae. A light microscopic (LM) and Scanning Electron Microscopic (SEM) study unraveled various morphological features of the cypsela. Among them, apical part, wall surface, surface hairs, nature, structure and arrangement of carpopodium, and stylopodium are taxonomically important traits. Furthermore, presence or absence of glands in wall surface, pappus bristles, testal nature, distribution of crystal and in pericarp and/or testa and endosperms of cypselas can also be considered as taxonomically significant. Distinct differences were observed between two taxa for many characteristics. Notable among these were occurrence of stylopodium, size of cypsela (without pappus), nature of pappus, thickness of pericarp, presence or absence of ribs, layer of radially elongated cells in mesocarpic sclerenchyma ans parenchyma, presence of additional uniseriate palisade like sclerenchymatous layer in $V$. anthelmintica, but not in $V$. cinerea, testal epidermal layer, nature of endosperm layer, and crystal formation. Similarities between two taxa were also noted. Based on structural manifestations of cypsela at morphoanatomical levels, an indented dichotomous key is provided for identification of studied taxa.
\end{abstract}

Talukdar, T. 2015. Taxonomic significance of Cyspsela in Vernonia anthelmintica Willd. and V. cinerea Less. (Asteraceae; tribe - Vernonieae): Structural manifestations. Plant Science Today 2(4): 107-115. http://dx.doi.org/10.14719/pst.2015.2.4.129

\section{Introduction}

Family Asteraceae is regarded as the largest family of Angiosperms comprising of more than 1,600 genera and 23,000 species of the flowering plants (Funk et al., 2009) with large number of herbal medicinal plants (Manjunatha et al., 2005; Chethan et al., 2012; Talukdar and Talukdar, 2013a; Marwat et al., 2015; Danalakshmi et al., 2013). In India, this family is represented by approximately 900 species under 167 genera (Mukherjee and Sarkar, 2001). The tribe Vernonieae was one of the original tribes, and consistently recognized in subsequent treatments within the family Asteraceae (Cronquist, 1977; Jones 1977; Bremer, 1987). In more restricted sense, Vernonieae are part of sub-family Cichorioideae. Occurrence of narrow styles and long sweeping hairs differ the trbe from Arctotideae and Moquinieae, whereas usual lack of milky sap and the common actinomorphic corollas has differentiated it from Cichorieae. The tribe contains 126 currently recognized genera and about 1500 species (Keeley and Robinson, 2009), mostly distributed in tropical parts of the world. Most of the species are assembled in the huge genus Vernonia, known as ironweeds in North America (Mukherjee and Nordenstam, 2004). It has two centers of distribution, one in Africa and other one in South America (Gleason, 1906). Old world species of Vernonia have a basic chromosome number of $\mathrm{X}=9$ or 10 , and New world species have a basic number of $X=$ 17 (Jones, 1977). Root tip mitosis of $V$. anthelmintica exhibited $2 \mathrm{n}=2 \mathrm{x}=20$ chromosomes, while $V$. cinerea showed $2 \mathrm{n}=2 \mathrm{x}=18$ chromosomes composing both metacentric and submetacentric chromosomes (Mathew and Mathew, 1982). Vernonieae are notable for the frequent extreme cymose forms involving scorpioid cymes and a unique chemical vernolic acid and the tribe is probably most primitive among the tribes of the family Asteraceae (Jones, 1977; Robinson et al., 1980). A good introduction to the detailed characters of the Vernonieae with a limited scanning electron micrograph (SEM) survey of Vernonieae pollen types has been given by Robinson (2009). 
Table 1. Sources along with collection number of studied materials in tribe Vernonieae of Asteraceae

\begin{tabular}{cll}
\hline Taxa investigated & Locality & Collection Number \\
\hline $\begin{array}{c}\text { Genus - Vernonia Schreb. } \\
\text { Species }- \text { V. } \text { anthelmintica } \\
\text { V. } \text { cinerea } \text { Less. }\end{array}$ & Denmark (DK) & GE 2204-0001 \\
\hline
\end{tabular}

Regarding the cypselar morphology in the tribe Robinson (2009) described that achenes were usually prismatic, rarely angled, 3-20 costate, and rarely with phytomelanin; carpopodium was stopper-shaped to turbinate but was rarely obsolete. Pappus possessed long capillary bristles. V. anthelmintica and V. cinerea, two members of tribe Vernonieae, are commonly distributed in India (Talukdar, 2013a,b; Biswas et al., 2014). Flower morpho-variants are available in $V$. cinerea (Manjunatha et al., 2005; Bala and Gupta, 2013).

The fruits of Asteraceae are very distinct from fruits of other families. The cypsela, fruit of Asteraceae, differed from the achene by an additional layer (perianth) over the pericarp due to the inferior position of the ovary; however, many plant scientists have continuously used the wrong term achene (Judd et. al., 2002). Marzinek et al. (2008) adopt the term cypsela as a complex fruit, dry, indehiscent, unilocular, with a single seed not adnate to the pericarp (linked only by the funicle) and originating from an inferior ovary. Cypsela and pappus are two morphological features which are aiding in taxonomic classifications at tribal levels of Asteraceae (Talukdar, 2008; Frangiote-Pallone and Antonio de Souza, 2014; Talukdar and Mukherjee, 2014). It is off-course Bipontinus (1844), who was the first to draw the attention of taxonomists toward the potentiality of cypselar anatomical features and used them in the classification of taxa in the Asteraceae. Morpho-anatomical study of cypsela in different species of Vernonia has been conducted (Bar et al., 2012; Jana et al., 2013) but considering the complexity and variations of the features even in same species of Vernonia collected from different geographical regions (temperate and tropical), more study need to be carried out. Present endeavor was therefore carried out to explore the taxonomic significance of cypsela through morpho-anatomical manifestations of $V$. anthelmintica and $V$. cinerea of the family Asteraceae.

\section{Materials and Methods \\ Collection of plant materials}

Plant materials (cypselas) for the present investigation were collected by the author and obtained in the form of received herbarium specimens (as gifted to Prof. Sobhan Kumar Mukherjee, Department of Botany, University of Kalyani, India) from the following herbarium of the world which are mentioned in Index Herbarium (Holmgren et al. 1981).

DK : Hortus botanicus Hauniensis, Denmark.

The present study includes two species of genus Vernonia i.e., $V$. anthelmintica Willd. and $V$. cinerea
Less. of the family Asteraceae. Under the tribe the species are alphabetically arranged with mentioning the locality and collection number of each species (Table 1).

For investigating stable and perfect stage of each character only fully matured and intact cypselas were collected. Fresh specimens were collected mainly from Nadia $\left(23^{\circ} 24^{\prime} \mathrm{N} / 88^{\circ} 30^{\prime} \mathrm{E}\right)$ and North 24-Parganas $\left(22^{\circ} 08^{\prime} \mathrm{N} / 88^{\circ} 30^{\prime} \mathrm{E}\right)$ of Gangetic West Bengal and few from Darjeeling $\left(27^{\circ} 02^{\prime} \mathrm{N} / 88^{\circ} 10^{\prime} \mathrm{E}\right)$ district of SubHimalayan West Bengal, India. During collection, field characters were carefully noted. In case of heterogamous capitula, both the ray and disc cypselas were placed in separate packets with proper labeling denoting date, locality and number of specimen. Collected cypselas were properly air-dried and kept in desiccators for better maintenance. Few cypselas of each species were also fixed in FAA (Formaldehyde, Acetic acid, Alcohol) solution, in addition to usual dry collection.

All the locally collected specimens were compared and verified in the Central National Herbarium, Calcutta (CNH, CAL) and all the voucher duplicate specimens were deposited in the Herbarium of the Department of Botany, University of Kalyani, Kalyani 741 235, Nadia, West Bengal, which was designated as "KAL”.

\section{Macro-morphological studies of cypselas}

In cases, where intact cypselas were available, the first and foremost step was to mark the posterior and anterior (abaxial) surface of the cypselas. Then 10 dry and 10 FAA preserved mature cypselas were randomly taken in glass slides and graphed slides and observed under Olympus stereo dissecting microscope (DM) and Olympus binocular microscope (No.-611062). Suitable images were taken using Zeiss Stemi DV4 camera equipped microscope.

Colours, shape, direction of cypselas were noted carefully. Length and width of the cypselas were measured visually by graphed slides, in few cases they were counted by ocular and stage micrometer. The length of the cypselas in the present study is defined as the length of the body of cypselas from basal meristematic zone (carpopodium) up to apical end excluding pappus. The width of the cypselas was measured at the widest part of the cypselar body. In case of heteromorphic cypselas, all the characters were studied for both the ray and disc cypselas and were noted separately. Outline diagrams of complete cypsela 
and different cypselar part were drawn by the Mirror type camera lucida.

\section{Micro-morphological studies of cypselas}

Mature cypselas were dipped in 1-5\% $\mathrm{NaOH}$ solution for 2-7 days depending upon the hardness. Then they were transferred into saturated chloral hydrate solution for few hours, repeatedly washed with water and properly stained in 0.2-0.5 \% aqueous Safranin solution. After staining, specimens were placed in $70 \%$ phenol glycerine solution and dissected carefully for studying different parts of cypselas. Suitable photographs were taken using Olympus C-310 zoom digital camera (3.2 Megapixel) and Zeiss-stereo microscope.

Nature of ribs, types, distribution and orientation of hairs, nature of surface cells, other epidermal structures, carpopodial cells etc. all were critically observed. Pappus characters such as nature of pappus bristles, their number, arrangement, colour, length, apex organization etc. were also examined.

\section{Anatomical studies of cypsela}

For anatomical studies, mainly hand sections of cypselas were utilized for examining the internal structures. Generally sections were made from the middle part of mature cypsela. The cypselas were dipped in different chemicals for different duration of times depending upon the hardness of wall, such as -

1. Cypselas were softened by dipping in boiling water for 5-30 minutes, with a few drops of glycerol

2. They were softened sometimes, by putting in $2 \mathrm{~N} \mathrm{NaOH}$ solution for 1-10 hours.

3. Sometimes they were placed in picric acid solution for few hours or inserted within lactophenol solution or $70 \%$ phenol-glycerine solution and boiled in water bath for 10-60 minutes.

After softening and sectioning, the sections were dehydrated and stained using conventional method (Johansen, 1940) with alcohol grades. A thorough study were undertaken to examine the following characters such as - nature of cells, their orientation, arrangement, wall thickness, shape of different cells comprising the different pericarpic layers. Any other structures for example, crystals, secretary ducts, cavity, vascular trace, resin ducts etc. also marked. All the observed features of cross-section were documented with the aid of camera lucida drawings.

\section{SEM studies of cypselas}

For SEM analysis, 5 matured and air dried cypselas of each species were selected randomly. They were mounted on labeled aluminium brass stubs with the help of double-stick cellophane tape. To obtain more analytical images, different angle views were taken by placing the cypsela obliquely. Along with normal surface features such as surface cells, ornamentations, trichome, gland, crystals etc. few localized observations were also made putting different parts of cypsela such as carpopodium, apical part or pappus separately on the stub with proper markings. All the carrying stubs were quick-dried using vacuum evaporator. During microscopic observations, all possible and suitable microphotographs of each specimen were taken using FEI - QUANTA 200 Autoscanning Electron Microscope at Regional Sophisticated Instrumentation Centre (RSIC), Bose Institute, Kolkata.

Terminology for the macro as well as micromorphological features, anatomical structures and SEM observations primarily follows Ramayya (1962), Barthlott (1981) and partially improvised by the author himself.

\section{Results}

\section{Vernonia anthelmintica Willd.}

\section{Cypselar morphology}

Cypsela homomorphic, $4.2-4.3 \times 1.0-1.5 \mathrm{~mm}$. in size (excluding pappus), blackish brown in colour, narrow oblong in shape, straight, truncate at the apex and gradually tapered towards the base, faintly dorsiventrally compressed, ribbed; ribs ten in number, prominent and straight. Surface was pubescent with pilose hairs covering, very closely appressed on both sides, antrorse in orientation, non-glandular, body undifferentiated, multicellular, biseriate, and flagellate, with sharply pointed apex. After clearing, cypselar wall surface shows glandular markings due to presence of rounded reddish and bilobed greenish glands (Fig. 1AJ). Stylopodium was ill-developed and narrow. Carpopodium symmetric, complete, circular, smooth, ring like; cells' outline visible and distinguishable from other cells of the cypsela, cells thin walled, round to oval, compactly arranged, tangentially oriented, parenchymatous, arranged in 14-15 rows; diameter of carpopodium same as the base of the body. Insertion of cypsela was straight, basal. Cypsela was pappose; outer pappus represented by many deciduous, capillary with squamellae (scale like), $0.25 \mathrm{~mm}$. long, inner bristles not found (Fig. 1A-J).

\section{SEM survey of cypsela}

Surface cells visible; square to rectangular, vertical, anticlinal and periclinal wall straight. Surface strongly ribbed with simple hairs and vescicular bodies. Vescicular body glandular, equally bilobed, few with apical depressions (Fig. 1A-F). Stylopodium was illdeveloped, narrow. Pappus was tri-seriate. Carpopodium symmetric, complete, circular, smooth, ring like; cells' outline visible and distinguishable from other cells of the cypsela, cells thin walled, round to oval, compactly arranged, tangentially oriented, parenchymatous, arranged in 14-15 rows; diameter of carpopodium same as the base of the body (Fig. 2 A-D).

\section{Cypselar anatomy}

Cypsela oblate in transaction with ten prominent, triangular ribs. Cypselar wall $367 \mu$. and $233 \mu$. wide at rib and furrow region respectively. Pericarp thick, on 
an average $229.0 \mu$. wide, differentiated into two zones, namely - epicarp and mesocarp (Fig. 3A-H).

A) Epicarp - uniseriate, made up of thin walled, rectangular, compactly arranged, tangentially oriented, parenchymatous cells. Cuticle was present.

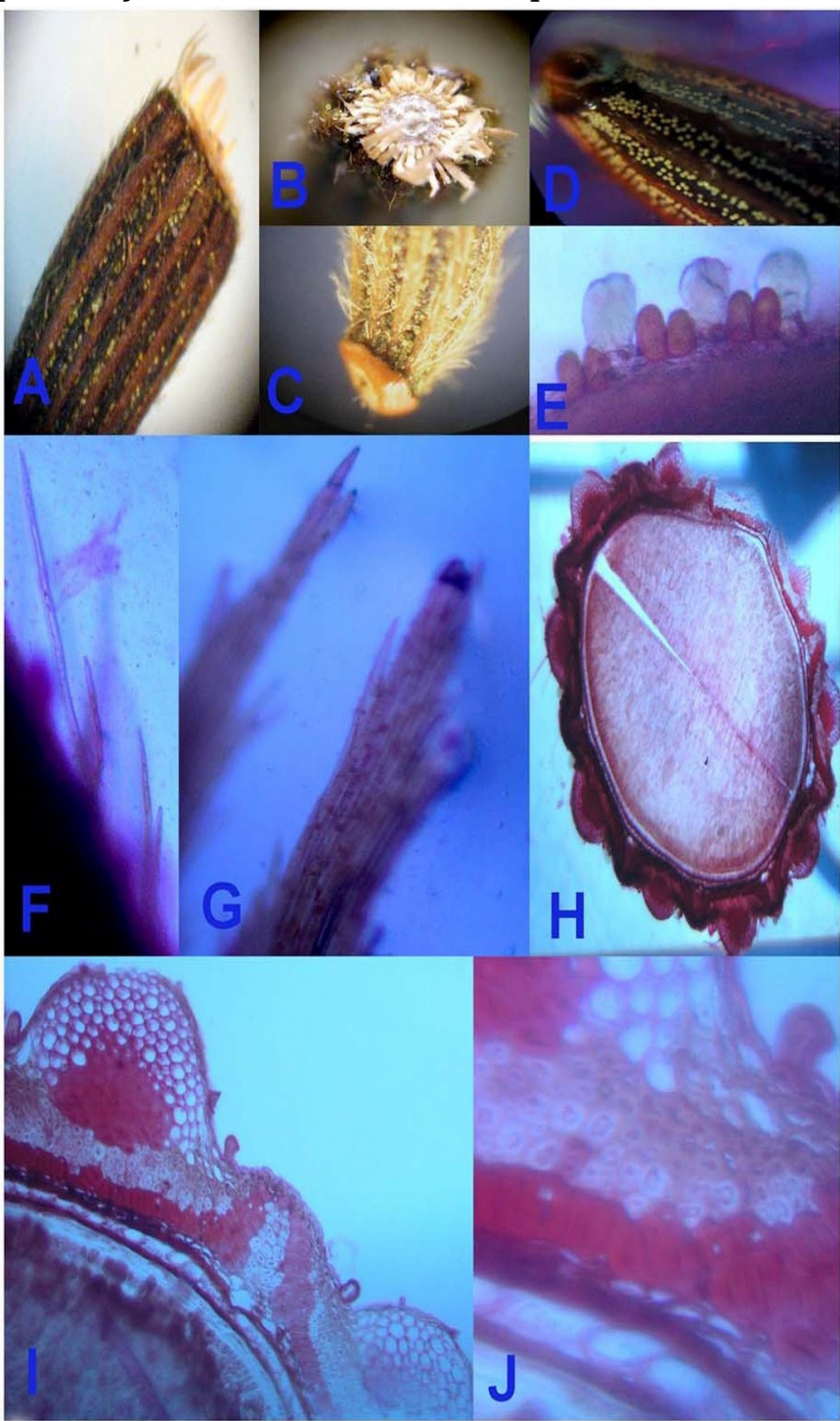

A-D x 30; E-H x 170; I x 270; J x 725.

Fig. 1. A-J: Vernonia anthelmintica; A-cypsela, B-apex, C-base with carpopodium, D-surface with glands, E-surface glands, F-surface hairs, G-parts of pappus, H-T.S. of cypsela, I \& J-parts of cypsela in T.S. (A-D ×30; E-H ×170; I × 270; J × 725) (specimen number- GE 2204-0001).

B) Mesocarp - consists of different types of tissues and structures as follows (from outside to inner zone )-

1) Parenchyma tissue - uniseriate at furrow and six to seven seriate at rib. Cells thick walled, polygonal, compactly arranged, parenchymatous. Few cells contain prismatic crystals (Fig. 3I).

2) Sclerenchyma tissue - present as continuous zone of uniseriate layer at furrow and three to four seriate layer at rib. Cells thick walled, rounded to oval, compactly arranged, sclerenchymatous, with very narrow elongated lumen. Outside of sclerenchyma tissue discreate sclerotic braces made up of discontinuous cylinder of cells present at each rib.

3) Palisade tissue/layer - present as continuous, wavy zone of single layer of cells thick. Cells thickwalled, oval palisade like, sclerotic with narrow elliptic lumen, filled with ergastic matters, compactly arranged. This wavy layer forms a curvature at furrow, which filled with parenchymatous cells.

Testa/seed coat - attached with pericarp, approximately $38.2 \mu$ thick, differentiated into outer and inner zones; outer zone made up of compressed and collapsed parenchyma cells. Inner zone cellular, unilayered, organized, made up of thin-walled, Ushaped, compactly arranged, tangentially oriented, parenchymatous cells (Fig. 3A-H).
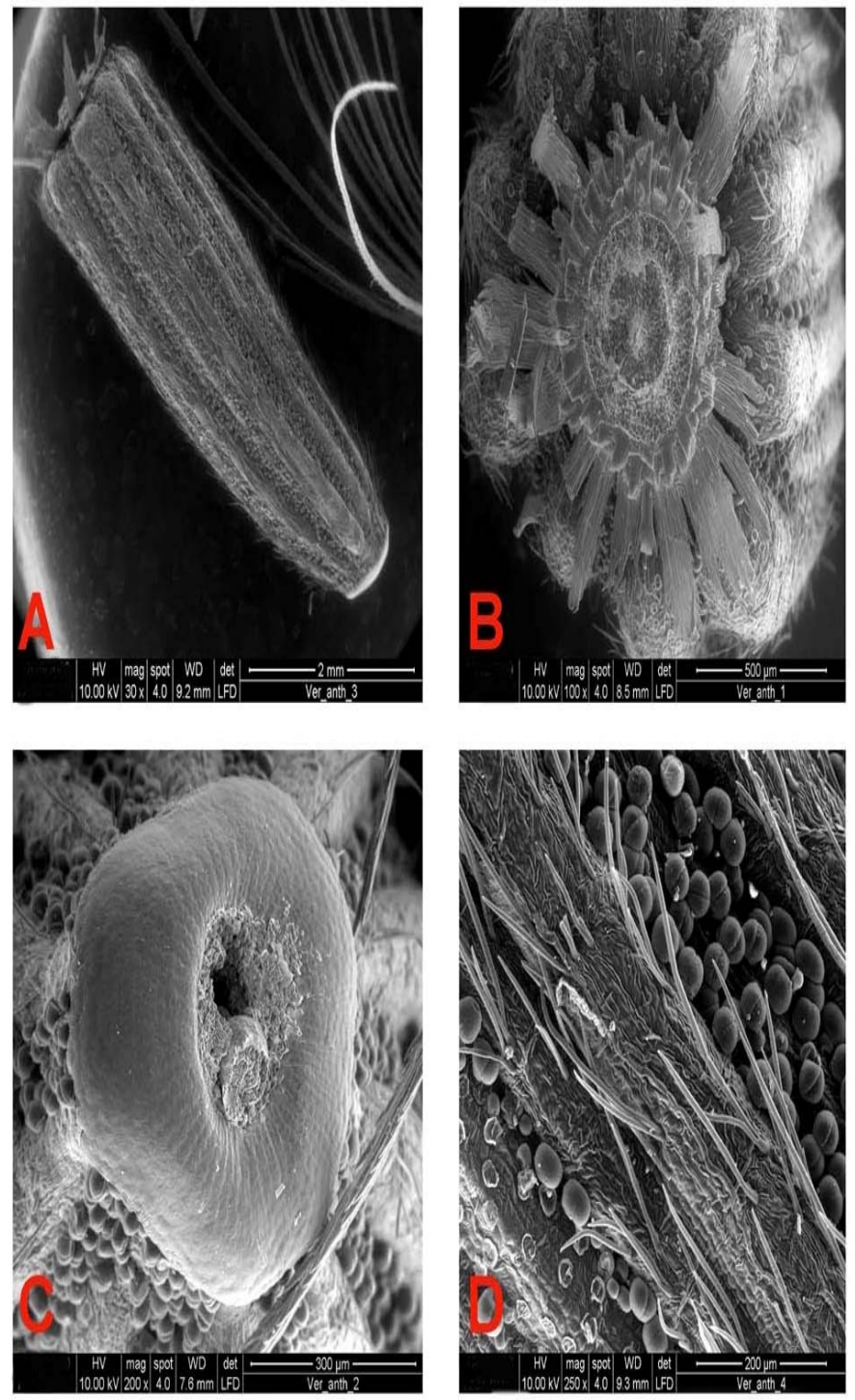

Fig. 2. A-D: Vernonia anthelmintica; A-cypsela, B-apex, Ccarpopodium, D-surface glands and hairs (specimen number- GE 2204-0001).

Endosperm - persists in mature cypsela, biseriate, cell layers slightly separated from each other. Cells of both the layer were thick-walled, barrel-shaped, 
compactly arranged and tangentially oriented, parenchymatous cells. Embryo - mature embryo occupied a major portion of the cypsela; cotyledons two in number, plano-convex in shape, anterior-posteriorly oriented; secretory duct in each cotyledon three in number, of which central one larger than others (Fig. $3 \mathrm{G}, \mathrm{H})$.
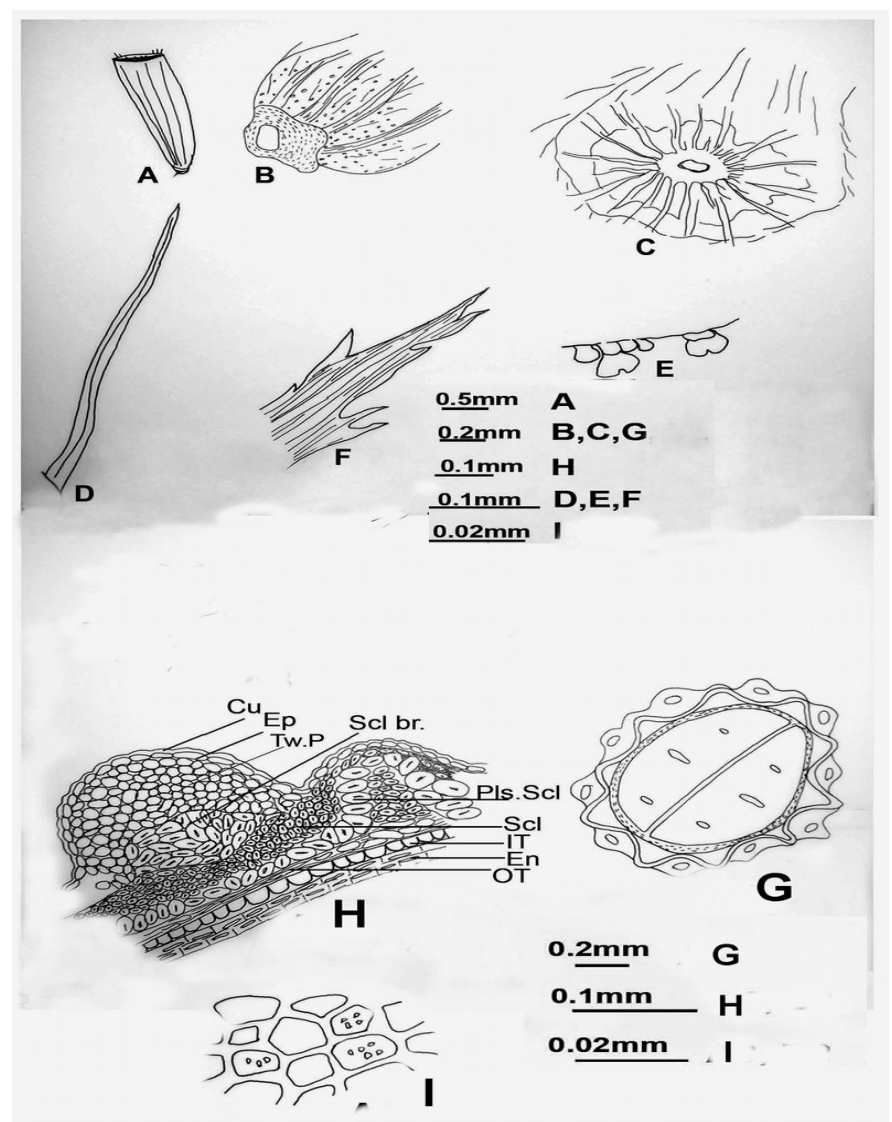

Fig. 3

Fig. 3. Vernonia anthelmintica; A-cypsela, B-base, C-apex, Dsurface hair, E-glandular surface hair, F-part of pappus, G-T.S of cypsela, H-a part of cypsela in T.S, I-mesocarpic parenchymatous cells with crystals (specimen number- GE 2204-0001).

\section{Vernonia cinerea Less.}

\section{Cypselar morphology}

Cypsela homomorphic, $1.7-2.0 \mathrm{~mm} \times 0.52-0.60 \mathrm{~mm}$. (excluding pappus), deep brown in colour, oblong in shape, straight, truncate at the apex and slightly tapered towards the base, sub-teret in transcetion, slightly dorsiventrally compressed but not differentiated, without any rib. Surface is pubescent with pilose hair covering. Hairs sparsely distributed on both surfaces, antrorse, non-glandular, forked type, differentiated into foot and body; foot simple, more or less same in diameter as the base of the body cells; body un-differentiated, multicellular, biseriate, filiform, aseptate, with sharply pointed apex, tips of the body cells situated in slightly different planes. After clearing, the cypselar wall, surface shows numerous small, rounds, glossy vesicular structures, arranged in several vertical rows (foveate). Surface cells were thin- walled, parenchymatous. Stylopodium was absent. Carpopodium present; symmetric, complete triangular ring like, cells' outline visible, six to seven rows thick; cells rectangular to elongated, thin-walled, radially oriented, distinguishable from other cells of the cypsela; diameter of carpopodium same as the base of the body(Fig. 4 A-H). Carpopodium bears a single vascular supply. Insertion of cypsela was straight, basal. Cypsela pappose; pappus represented by many, double, outer deciduous and inner persistent, terete, barbellate filiform bristles, free from one another, 4.2$4.8 \mathrm{~mm}$ long, white in colour. Tip of the lateral cells elongated and approximately as long as width of the rachis of the bristles, apex made up of two, more or less equal cells with pointed tips (Fig. 4 A-H).

\section{Cypselar anatomy}

Cypsela transversely elliptic in transaction. Cypselar wall $31.25 \mu$. wide. Pericarp thin, $25 \mu$. wide, differentiated into two zones, namely - epicarp and mesocarp (Fig. 5A-H).

A) Epicarp - uniseriate, made up of thin walled, oval to rounded, tangentially oriented, parenchymatous cells; persistent hair bases and vesicular cells present.

B) Mesocarp - consists of different types of tissues and structures as follows(from outside to inner zone)

1) Sclerenchyma tissue - present as continuous unilayered zone of cells; cells thick-walled, oval, radially elongated, sclerenchymatous with elongated large lumen.

2) Parenchyma tissue - uniseriate, continuous. Cells thin-walled, oval, tangentially oriented, compactly arranged. Two vallecular ducts present at 2 corners, just inside the parenchyma zone.

Testa/seed coat - adpressed with pericarp, approximately $6.9 \mu$ thick, un-differentiated, disorganized represented by collapsed parenchyma.

Endosperm - persists in mature cypsela, uniseriate, cells thick-walled, barrel-shaped, tangentially oriented, parenchymatous. Embryo - mature embryo occupied more or less the entire portion of the cypsela; cotyledons two in number, plano-convex in shape, anterior-posteriorly oriented; secretory duct in each cotyledon-three in number, of which central one larger than others.

\section{Key character to the Vernonia}

Cypselas 5-10 costate; pappus almost always double; carpopodium symmetrical, ring-like; insertion of cypselas straight, basal; testa adpressed with pericarp; secretory duct in each cotyledon three in number.

\section{Key to the species of Vernonia}

1a. Hairs non-forked; stylopodium ill-developed, narrow; pericarp thick

$(229 \mu)$, with 3 mesocarpic layers, palisade sclerenchyma present, crystals

present; testa differentiated with U-shaped testal cells; endosperm

biseriate. 
Vernonia anthelmintica

1b. Hairs forked; stylopodium absent; pericarp thin $(25 \mu)$, with 2 mesocarpic

layers, palisade sclerenchyma absent, crystal absent; testa un-

differentiated without U-shaped testal cells; endosperm uniseriate.

\section{Vernonia cinerea}

$\begin{array}{llllll}\text { Vernonia anthelmintica } & \text { VERN } & 25 & 19 & 11 & 26\end{array}$ 19

$\begin{array}{lllllll}\text { Vernonia cinerea } & \text { VERN } & 25 & 20 & -26 & 20\end{array}$

\section{Discussion}

Cypsela and pappus morphology undoubtedly provide immense taxonomic inputs for classification and phylogeny of Asteraceae (Talukdar, 2013a; Talukdar and Mukherjee, 2014). Cypsela and pappus morphology together with growth form, capitula size, florets, involucral bracts and leaf shapes were used in separating Anthemideae into 12 sub-tribes of Asteraceae (Bremer and Humphries, 1993). Present investigation revealed that the external and internal features of cypselas including pappus under LM and SEM study provide valuable information about the genus Vernonia.

Two different species of Vernonia are examined by LM and SEM, namely - (i) V. anthelmintica and (ii) $V$. cinerea. In both the species cypsela homomorphic, blackish brown to deep brown in colour, oblong, straight, truncate at the apex and tapered toward the base. Cypsela was weakly dorsiventrally compressed with ten prominent ribs, which was in accordance with the previous view of Misra (1972). However ribs totally absent in $V$. cinerea. Cypselas of both the species are hairy/trichomatous with pilose hair covering. Hair nonglandular, biseriate, non-forked in $V$. anthelmintica but forked (twin type) in $V$. cinerea. Presence of such biseriate forked hairs in the genus Vernonia is also reported by Narayana (1979) and Sahu (1984). The use of trichomes as one of the determining taxonomic criteria is well established not only in the family Asteraceae but for other family also. Hunter and Austin (1967), noted that evidence of hybridity of $V$. guadalupensis between $V$. interior and $V$. tindheimeri as obtained from morphological studies, field observations, herbarium studies as well as chromatographic data, were also supported from trichomes morphology. Narayana (1979) worked on the structure of vegetative trichomes of 15 species of Vernonia in South India and recognized 3 types of trichomes from the cypselas. He designated "twin hair" as 'Biseriatenforked hair', whereas Sahu (1984) reported six types of trichomes from the cypselas of 20 taxa of Vernonia. The twin hair has been designated by him as 'Achenial hair'. Mukherjee and Sarkar (2001) carried out a detailed analysis of macro-morphological and anatomical features of mature cypselas of 18 species belonging to 6 genera of the tribe Vernonieae, and found more or less uniform surface twin hairs with few exceptions. Recent study opined that although the trichomes may have taxonomic significance, the socalled twin hairs, which are very characteristic of the pericarp of many Compositae (Asteraceae) (Roth,1977), are of no taxonomic value, as very distinct types occur within the same subfamily and even within the same genus (Frangiote-Pallone and Antonio de Souza, 2014). Hair character can be used successfully to delimit genera within the family Asteraceae, as for example the genus Vernonia can be delimited from other genera by the presence of T-shaped hair and Chromolaena has amoeboid shaped hair etc (Adedeji and Jewoola, 2008).

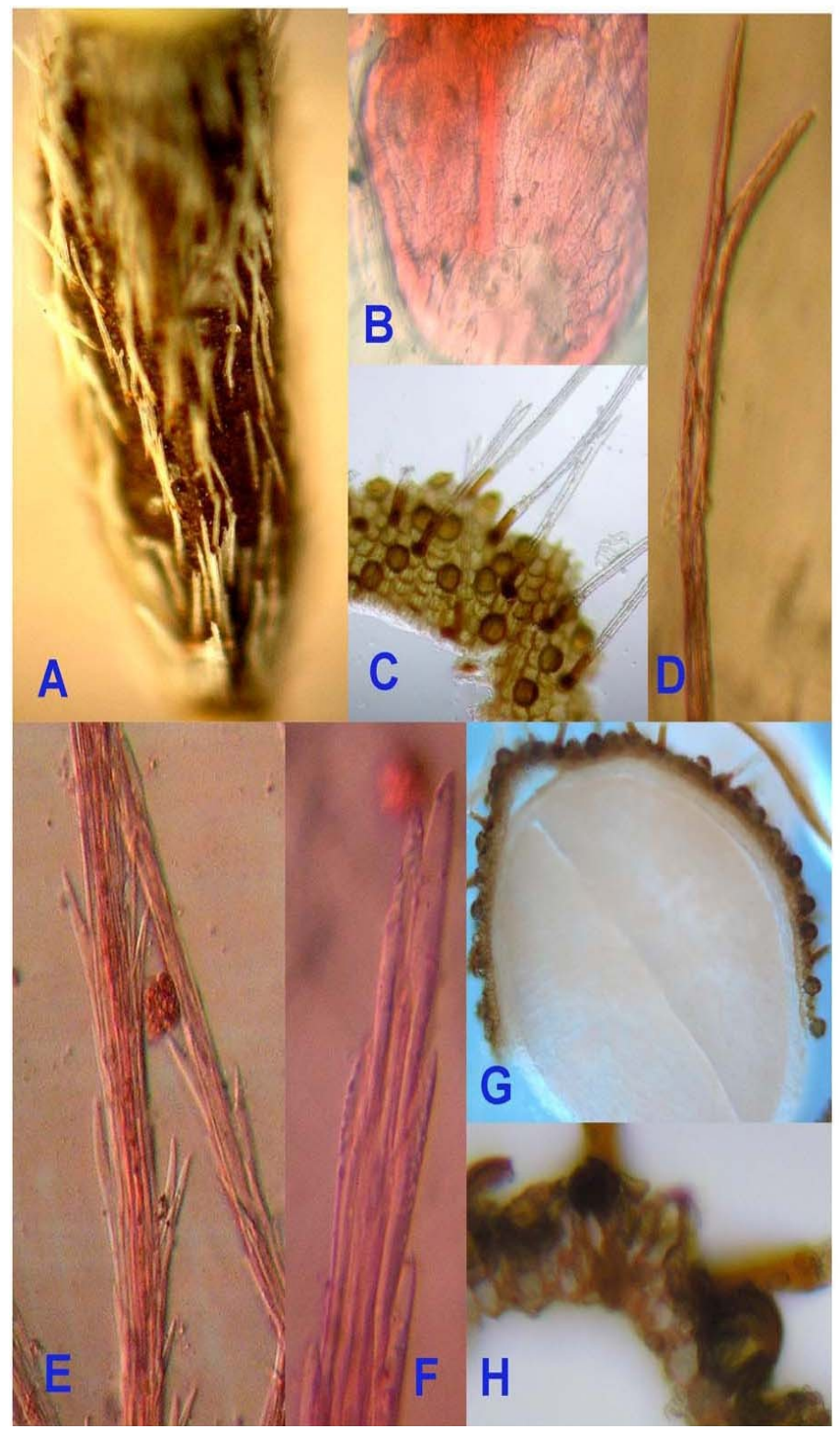

Fig. 4. Vernonia cinerea; A-cypsela, B-carpopodium, C-surface with hairs and vesicular structures, D-twin hair, E-middle part of bristle, F-apical part of bristle, G-T.S. of cypsela, H-part of cyspsela in T.S. $(A \times 75 ; B, C, G \times 170 ; \mathrm{D}-\mathrm{F}, \mathrm{H} \times 725)$ (specimen number- TT-01).

After clearing the cypselar wall, the surface shows glandular or foveate marking. Among the studied taxa, 
$V$. cinerea do not possess stylopodium but $V$. anthelmintica bears ill-developed, narrow stylopodium. However, partially immersed, well developed style base have been noted in other species of Vernonia like $V$. gracilis and V. senegalensis by Mukherjee and Sarkar (2001) and Mukherjee (2005). Consistent occurrence of non-interrupted and complete ring like carpopodium in the present two species is in agreement with earlier notes given by Mukherjee and Nordenstam (2004). Another study with 18 species belonging to 6 genera (Bothriocline, Centratherum, Elephantopus, Rolandra, Vanillosmopsis and Vernonia ) of the tribe Vernonieae with the aid of LM and SEM revealed that the tribe Vernonieae has many primitive features from the cypselar point of view like - (i) beakless cypsela, (ii) presence of vesicular bodies in most taxa, (iii) presence of symmetrical carpopodium usually formed by many cell layers, (iv) pappus represented by scabrous bristles or scarious or seta ceous scales. The results suggested that the tribe can be regarded as one of the most primitive tribe in the Asteraceae (Mukherjee and Sarkar, 2001). Present results with more insights in cypselar features further confirmed these findings.
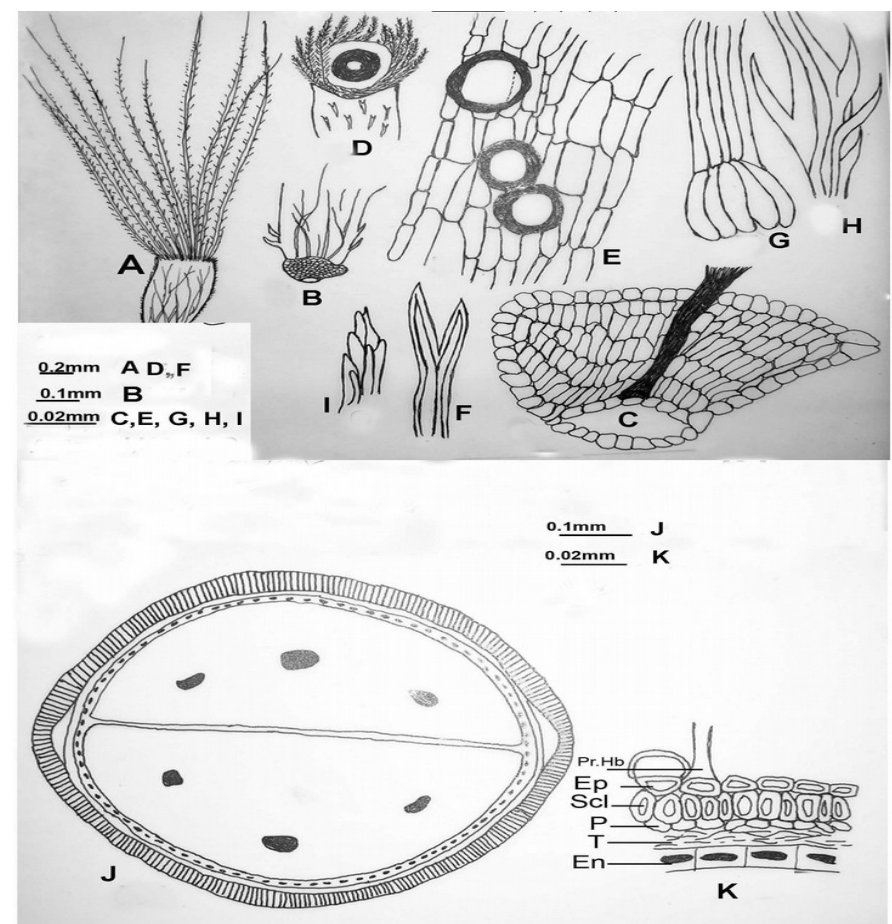

Fig. 5. Vernonia cinerea; A-cypsela, B-base, C-carpopodium, Dapex, E-cypselar wall after cleaning, F-surface hair, G-I-basal part, middle part and apical part of pappus bristle, respectively, J-T.S. of cypsela (diagrammatic), and $\mathrm{K}-\mathrm{a}$ part of cypsela in T.S. (specimen number- TT-01).

Widespread variations within the genus Vernonia were noticed regarding the size of cypselas. Bar et al. (2013) reported smallest cypsela in V. gracilis $(1.5 \mathrm{~mm} \times$ $1.0 \mathrm{~mm}$ excluding pappus) and largest cypsela in $V$. diffusa (3.2 $\mathrm{mm} \times 0.7 \mathrm{~mm}$ excluding pappus). In the present study, cypsela (excluding pappus) in $V$. anthelmintica exhibited nearly 1.3-2-fold higher size than these two species but size was comparable to $V$. gracilis in case of $V$. cinerea. Cypsela shapes have not been particularly useful for grouping the species but can be used for species delimitation (Mukherjee and Nordenstam, 2010). In the present study, occurrence of narrow ( $V$. cinerea) to narrow-oblong ( $V$. anthelmintica) cypsela are suggestive of the above concept.

In Asteraceae, pappus plays an important role in the dispersal of seed which has been regarded as one of the powerful mechanisms of colonization of some of the weedy daisies such as Parthenium hysterophorus, Eupatorium odoratum, Ageratum conyzoides to spread as worst invasive and alien flora with high allelopathic effects on native plants in India (Marngar and Kharbuli, 2003; Belgeri and Adkins, 2015; Wang et al., 2015). Pappus nature is diversified in Asteraceae (Mukherjee and Nordenstam, 2008; Talukdar, 2013a). Under Light microscope, pappus characters provide valuable information about the genus Vernonia. In both the species pappus dimorphic, usually of long capillary bristles. Both barbelate and scaly type of pappus present in $V$. cinerea. However, occurrence of only barbelate type of pappus bristles was reported in $V$ anthelmintica (Jana and Mukherjee, 2012; Taluldar, 2013a, b). Despite biseriate arrangement of pappus in present two species, uniseriate arrangement was not uncommon in other species of Vernonia (Basak and Mukherjee, 2003).

Presence of carpopodium is an another important features of cypselar morphology in Vernonia spp. Situated at the base of cypsela, carpopodium in both species exhibited comparable features with symmetric, ring like structure, and are distinguishable from other cells of cypselas.

\section{Cypselar anatomy}

Regarding anatomical features studied taxa showed minor to moderate variations. Cross section of mature cypselas of $V$. anthelmintica usually shows ten prominent triangular ribs and furrows, whereas in $V$. cinerea ribs are either absent or very inconspicuous. Pericarp is very thin (ca. $25 \mu$ in $V$. cinerea) to very thick (ca. $229 \mu$ in $V$. anthelmintica ) and clearly differentiated into two zones - epicarp and mesocarp. In both the species of Vernonia, epicarp is commonly uniseriate and homomorphic. A cuticle layer can be observed in $V$. anthelmintica. Mesocarpic zone shows considerable variations. In $V$. cinerea mesocarpic sclerenchyma tissue represented by a uniseriate layer of radially elongated cells, whereas in $V$. anthelmintica it is uni- to multiseriate with additional sclerotic braces at each rib. Mesocarpic parenchyma is uni- to multiseriate with thick-walled, polygonal cells in $V$. anthelmintica, whereas in $V$. cinerea this layer is uniseriate throughout with oval, thin-walled cells. Notably an additional uniseriate palisade like sclerenchymatous layer exists in $V$. anthelmintica, which is totally absent in $V$. cinerea. A unique mesocarpic zone was revealed in $V$ hymenolepis, where this zone shows an inverted ' $T$ ' shaped sclerenchymatous bundle near the ribs in the tribe Vernonieae (Mukherjee and Sarkar, 2001). The results suggested that the tribe Vernonieae has many 
primitive cypselar features like thick pericarp, absence of pitted parenchyma cells etc. (Mukherjee and Sarkar, 2001).

Taxa having well organized testal epidermis have been considered as primitive one compared to disorganized testal epidermis exhibiting testal epidermal cells lacking sclerification and wall thickening as advanced features (Reese 1989). In the present study, testa is often adpressed with the pericarp. It is differentiated into an outer non-cellular layer and an inner cellular layer in $V$. anthelmintica, whereas in $V$. cinerea it is totally un-differentiated and non-cellular, suggesting that testa is usually less specific and less distinct, as noted in different other members of Vernonieae (Jana and Mukherjee, 2014). However, occurrence of U-shaped cells in inner testal layer was found as unique in $V$. anthelmintica in the present study.

Endosperm also shows moderate variations among the studied taxa. It is uniseriate in $V$. cinerea but biseriate in $V$. anthelmintica. Embryos of both the species show rather uniformity. They occupied a major to entire portion of cypsela with two, parallely oriented, plano-convex cotyledons having three secretory ducts in each.

Calcium oxalate crystals and druses, found to be present in different plant parts including cypselar wall in some members of the family Asteraceae. Its significant role to detoxify heavy metals (Nakata, 2003; Talukdar, 2013c), as well as to overcome water and salt stress (Hurkman and Tanaka, 1996) along with other functions and its restricted occurrence in few taxa probably enough to consider it as a evolutionary important taxonomic tool. The presence of calcium oxalate (CaOx) crystals in different plant parts such as leaves, stems, roots, floral parts, fruits and seeds specially as intracellular granular deposits have been recorded from over 215 angiospermic families including Asteraceae (Franceschi and Nakata, 2005). In the present observation, few mesocarpic parenchyma cells manifested calcium oxalate crystals in $V$. anthelmintica. Basak and Mukherjee (2003) observed prismatic calcium oxalate crystals in $V$. blanda, $V$. hymenolepis and $V$. stenolepis of the tribe Vernonieae. In $V$. blanda and $V$. hymenolepis crystal found to be present only in sclerenchymatous tissue whereas in $V$. stenolepis crystals found in both sclerenchymatous and thick-walled parenchymatous tissue. Presence of such type of prismatic crystals in few other species of Vernonia has also been noted (Mukherjee and Nordenstam, 2010). Present results pointed out that distribution of crystals and druses in pericarp and/or testa is very useful and important for the tribes Vernonieae, as also found much important in Astereae, Inuleae (s.lato.), Senecioneae, Anthemideae and Cynareae and is less important in Arctoteae, Calenduleae, Pertyeae, Dicomeae, Mutiseae and Lactuceae (Mukherjee and Nordenstam, 2010). Unique features of pappus, trichomes, endosperms and crystals have recently been elucidated as potential biomarkers of toxic metalloid stress in organs of medicinal daisy, Wedelia chinensis (Talukdar, 2013b). The outcome of the present structural considerations of two members of Asteraceae assumes further significance in this regard.

\section{Conclusion}

The present investigation revealed taxonomic significance of cypselar morphological and anatomical features of two daisies namely $V$. anthelmintica and $V$. cinerea. LM and SEM study revealed sharp differences between two taxa as well as some uniformity in diverse aspects morpo-anatomical features of cypsela. Occurrence of lobed vescicular structure along with biseriate hairs all over the cypselar surface of $V$. anthelmintica is a unique feature and can be used in dual purposes such as potential taxonomic marker as well as easily observable stress responsive biomarker. Presence of well-differentiated distinct carpopodium can be used as species delimiting factor under the tribe Verbineae, Asteraceae.

\section{Competing interests}

Author declares that she does not have any competing interests.

\section{Acknowledgment}

The herbarium specimens from Denmark were given by Dr. Hans Vilhelm Hansen, Curator, whereas the herbarium specimens from Zurich were dispatched through the active assistance of Dr. Peter Enz, Curator. The guidance provided by Prof, Sobhan K. Mukherjee, Department of Botany, University of Kalyani during the study period is also gratefully acknowledged.

\section{References}

Adedeji, O. and O. A. Jewoola. 2008. Importance of leaf epidermal characters in the Asteraceae family. Not Bot Hort Agrobot Cluj 36(2): 7-16.

Bala, S. and R. C. Gupta. 2012. Male meiosis and chromosome number in Asteraceae family from district Kangra of H.P. (Western Himalayas). Int J Bot Res 3 (1): 43-58.

Bar, R., B. K. Jana, and S. K. Mukherjee. 2012. Morphological study of cypselas in 3 species of the tribe Vernonieae-Asteraceae. Int J Pharm Res Bio-Sci 1(6): 208-217.

Barthlott, W. 1981. Epidermal and seed surface characters of plants: systematic applicability and some evolutionary aspects. Nordic J Bot 1(3): 345-355. doi: 10.1111/j.17561051.1981.tb00704.X

Basak, N. and S. K. Mukherjee. 2003. Taxonomic significance of cypselar features in some species of Vernonia (VernonieaeAsteraceae) J Hill Res 16: 9-15.

Belgeri, A. and S. W. Adkins. 2015. Allelopathic potential of invasive parthenium weed (Parthenium hysterophorus L.) seedlings on grassland species in Australia. Allelopathy $J$ 36(1): 1-14.

Bipontinus, C. H. S. 1844. Anthemideae. In: P.B. Webb, and G. Berthelot. Phytographia Canariensis 1:244-304.

Biswas, S., M. Maity, G. Bhandari, R. Batabyal, J. Patra, A. Bhuiya, B. Ojha, N. Halder, and D. Talukdar. 2014. Floral diversity and ecology in Kalyani area of Nadia district, West Bengal, India. Plant Sci Today 2(1): 38-42. doi:10.14719/pst.2015.2.1.88

Bremer, K. 1987. Tribal Interrelationship of the Asteraceae. Cladistics 3: 210-253. doi: 10.1111/j.1096-0031.1987.tb00509.x

Bremer, K. and C. Humphries. 1993. Generic monograph of the Asteraceae-Anthemideae. Bulletin of the Natural History Museum, Botany Series 23: 71-177. 
Chethan, J., K. K. Sampath Kumara, S. Shailesree, and H. S. Prakash. 2012. Antioxidant, antibacterial and DNA protecting activity of selected medicinally important Asteraceae plants. Int J Pharm Pharm Sci 4(2): 257-261.

Cronquist, A. 1977. The Compositae revisited. Brittonia 29 (2): 137153. doi: $10.2307 / 2805847$

Danalakshmi, P., A.J.P. Priya, E. Sagadevan, Y. S. Laksmi, A. Mamimaran, S. Sindhu, and P. Arumugam. 2013. Evaluation of inhibitory effect of Vernonia cinerea L. leaf extracts on different fungal species. Int J Pharm Pharm Sci 5(2): 414-416.

Frangiote-Pallone, S. and L. Antonio de Souza. 2014. Pappus and cypsela ontogeny in Asteraceae: structural considerations of the tribal category. Rev Mex Biodivers 85: 62-77. doi: 10.7550/rmb.32809

Franceschi, V. R. and P. A. Nakata. 2005. Calcium oxalate in plants : formation and function. Annu Rev Plant Biol 56(1): 41-71. doi:10.1146/annurev.arplant.56.032604.144106

Funk, V. A., A. Susanna, T. F. Stuessy, and R. J. Bayer. 2009. Systematics, Evolution, and Biogeography of Compositae. IAPT, Vienna, Austria.

Gleason, H. A. 1906. A revision of the North American Vernonieae. Bull New York Bot Gard 4: 144-243.

Holmgren, P. K., W. Keuken, and E. K. Schofield. 1981. Index Herbariorum. Part I. In: The Herbaria of the World. Haque, Ed. 7, Regnum Vegetabile. p.106.

Hunter, G.E. and D. F. Austin. 1967. Evidence from trichome morphology of interspecific hybridization in Vernonia: Compositae. Brittonia 19: 38-41. doi: 10.2307/2805081

Jana, B. K. R. Bar, and S. K. Mukherjee. 2013. Cypselar morphology and anatomy of five species of the tribe InuleaeAsteraceae. Int J Pharm Biol Sci 4(1): 911-919.

Jana, B. K. and S. K. Mukherjee. 2014. Diversity of testal structure among some tribes of Compositae. J Sci 4(5): 327-338.

Johansen, D. A. 1940. Plant microtechnique. McGraw HilL, New York.

Jones, S. B. 1977. Vernonieae-systematic review. In : V. H. Heywood, J. B. Harborne, and B. L. Turner. Eds. The Biology and Chemistry of the Compositae, Vol. 1. Academic Press, London. p. 503-521.

Judd, W. S., C. S. Campbell, E. A. Kellogg, P. F. Stevens and M. J. Donoghue. 2002. Plant systematic - a phylogenetic approach. $2^{\text {nd }}$ Edition. Sinauer Associates, Sunderland. p. 576.

Keeley, S. C. and H. Robinson. 2009. Vernonieae. In: V. A. Funk, A. Susanna, T. F. Stuessy, and R. J. Bayer, Eds. Systematics, Evolution, and Biogeography of Compositae. Smithsonian Institution, Washington, D.C., USA. p. 439-469.

Marngar, D., and B. Kharbuli. 2004. Effect of Ageratum conyzoides extracts on the larvae of Metanastria lattipennis. Allelopathy J 14: 71-75.

Marwat S. K., Fazal-ur-Rehman, and I. U. Khan. 2014. Ethnobotanical importance and phytochemical constituents of Parthenium weed (Parthenium hysterophorus L.) - A review. Plant Sci Today 2(2): 77-81. doi:10.14719/pst.2015.2.2.113

Marzinek, J., O. C. De-Paula and D. M. T. Oliveira. 2008. Cypsela or achene? Refining terminology by considering anatomical and historical factors. Rev Bras Bot 31: 549-553.

Manjunatha, B.K., S.M. Vidya, K. V. Rashmi, K. L. Mankani, H. J. Shilpa, S. D. Singh Jagadeesh. 2005. Evaluation of woundhealing potency of Vernonia arborea. Indian J Pharmacol 37 (4): 223-226. doi: 10.4103/0253-7613.16567

Mathew, A. and P. M. Mathew. 1982. Studies on the South Indian Compositae IV. Karyomorphology of eight species of Vernonia Schreb. Cytologia 47: 163-169.

Misra, S. 1972. Floral morphology of the family compositae. Bot Mag (Tokyo) 85(3): 187-199. doi: 10.1007/BF02489211

Mukherjee, S.K. and A. K. Sarkar. 2001. Study of macromorphological and anatomical structures of cypselas of eighteen taxa of the tribe Vernonieae (Asteraceae). J Natl Bot Soc 55: 85-104.

Mukherjee, S. K. 2005. Comparative studies of stylopodium in some Asteraceae. In: A. K. Pandey, J. Wen, and J. V. V. Dogra, Eds. Plant Taxonomy :Advances and Relavance. CBS
Publishers \& Distributors, New Delhi, Bangalore, India. p.493-503.

Mukherjee, S. K. and B. Nordenstam. 2004. Diversity of carpopodial structure in the Asteraceae and its taxonomic significance. Compositae Newsl 41: 29-50.

Mukherjee, S. K. and B. Nordenstam. 2008. Diversity of pappus structure in some tribes of the Asteraceae. Phytotaxonomy 8: $32-46$.

Mukherjee, S. K. and B. Nordenstam. 2010. Distribution of calcium oxalate crystals in the cypselar walls in some members of the Compositae and their taxonomic significance. Compositae Newsl 48: 63-88.

Nakata, P. A. 2003. Advances in our understanding of calcium oxalate crystal formation in plants. Plant Sci 164(6): 901-909. doi: 10.1016/S0168-9452(03)00120-1

Narayana, B. M. 1979. Taxonomic value of trichomes in Vernonia (Asteraceae). Proc Ind Acad Sci, Sec B 88: 347-358. doi: 10.1007/BF03046107

Ramayya, N. 1962. Studies on the trichomes of some Compositae I. General structure. Bull Bot Surv India 4 (1-4): 177-188.

Reese H. 1989. Development of pericarp and testa in Calendulaceae and Arctotideae (Asteraceaea). Bot Jahrb Syst 110(3): 325-419.

Robinson, H. 2009. An introduction to micro-characters of Compositae. In: V. A. Funk, A. Susanna, T. F. Stuessy, and R. J. Bayer. Eds. Systematics, Evolution, and Biogeography of Compositae. Smithsonian Institution, Washington, D.C., USA.

Robinson, H., F. Bohlmann, and R. M. King. 1980. Chemosystematic notes on the Asteraceae. III. Natural subdivitions of the Vernonieae. Phytologia 46: 421-436.

Roth, I. 1977. Fruits of angiosperms. In: Encyclopedia of plant anatomy. K. Linsbauer, F. G. Tischler and A. Pascher, Eds. Gebrüder Borntraeger, Berlin. p. 258-291.

Sahu, T. R. 1984. Taxonomic implications of trichome complements to Vernonia (Compositae) in India. Feddes Repert 95(4): 237-249.

Talukdar, D. 2013a. Species richness and floral diversity around 'Teesta Barrage Project' in Jalpaiguri district of West Bengal, India with emphasis on invasive plants and indigenous uses. Biol Med 5: 01-14.

Talukdar, D. 2013b. Floristic compositions and diversity of weed taxa in lentil (Lens culinaris Medik.) fields. Bull Environ Pharmacol Life Sci 2(3): 33-39.

Talukdar, D. 2013c. Arsenic-induced oxidative stress in the common bean legume, Phaseolus vulgaris L. seedlings and its amelioration by exogenous nitric oxide. Physiol Mol Biol Plants 19(1):69-79. doi: 10.1007/s12298-012-0140-8

Talukdar, T. 2008. Comparative study of cypselas in three common species of Asteraceae. Pleione 2(1): 147-149.

Talukdar, T. 2013a. Cypselas diversity of the tribe -Cardueae (Asteraceae)- an overview. Lap Lambert Academic Publishing, Germany. p. 1-85.

Talukdar, T. 2013b. Fruit microcharacters as potential biomarkers of arsenic toxicity in a medicinal herb, Wedelia chinensis merill of Compositae. Int J Agric Sci Res 3(1): 143-150.

Talukdar, T. and S. M. Mukherjee. 2014. Cypselar diversity in four species of Senecio L. (Asteraceae). Bangladesh J Plant Taxon 21(1): 13-17.

Talukdar, T. and D. Talukdar. 2013a. Response of antioxidative enzymes to arsenic-induced phytotoxicity in leaves of a medicinal daisy, Wedelia chinensis Merrill. J Nat Sc Biol Med 4(2): 383-388. doi:10.4103/0976-9668.116989

Talukdar, T. and D. Talukdar. 2013b. Ethno-medicinal uses of plants by tribal communities in Hili block of Dakshin Dinajpur district, West Bengal. Indian J Nat Prod Resour 4(1): 110-118.

Wang, R, T. Dai, G. Quani, and J. Zhang. 2015. Changes in soil physico-chemical properties, enzyme activities and soil microbial communities under Mimosa pudica invasion. Allelopathy J 36(1): 15-24. 